\title{
The effect of the drying method on the cell wall structure and sorption properties of waterlogged archaeological wood
}

\author{
Magdalena Broda ${ }^{1,2}$ (D) Simon F. Curling ${ }^{2} \cdot$ Marcin Frankowski $^{3}$
}

Received: 25 December 2020 / Accepted: 29 April 2021 / Published online: 9 May 2021

(c) The Author(s) 2021

\begin{abstract}
Drying is a process affecting various wood properties, including its structure, moisture behaviour and mechanical properties. Since waterlogged wooden artefacts usually constitute priceless objects of cultural heritage, understanding the effect of drying on the complex interactions between the wood ultrastructure and the resulting properties is necessary to ensure their proper conservation. Hence, this was the aim of the present study, with a particular emphasis on the influence of drying conditions on the relations between the cell wall structure, dimensional stability and hygroscopicity of degraded archaeological wood. The choice of the particular drying methods was dictated by their final effect on wood appearance (dimensions). The results obtained clearly show that depending on the drying method applied, the resulting material differs significantly in structure, dimensions and sorption properties, despite the same degree of wood degradation. Air- and oven-drying resulted in the highest wood shrinkage, lower porosity, and a decreased number of free hydroxyls in the wood cell wall. The best wood dimensional stabilisation and the highest porosity were ensured by freeze- and supercritical drying. No correlations were found between wood structure and moisture behaviour. The outcome of the research may be useful for conservators who plan to provide the artefacts with proper storage conditions and effective conservation/reconservation.
\end{abstract}

Magdalena Broda

magdalena.broda@up.poznan.pl

1 Department of Wood Science and Thermal Techniques, Faculty of Forestry and Wood Technology, Poznań University of Life Sciences, ul. Wojska Polskiego 38/42, 60-637 Poznań, Poland

2 BioComposites Centre, Bangor University, Bangor, UK

3 Department of Analytical and Environmental Chemistry, Faculty of Chemistry, Adam Mickiewicz University in Poznań, Poznań, Poland 


\section{Introduction}

Wood is a porous and hygroscopic material. The microstructure and rheological behaviour of the cell wall is closely intertwined with its moisture properties, chemical composition, and the quality of particular wood polymers (Cave 1978; Salmén 2015). In the case of waterlogged archaeological wood, however, the relationships between composition, structure, moisture behaviour and mechanical properties become even more complex. First of all, the porosity of such wood acquires a different meaning due to chemical and physical changes within the cell wall caused by its degradation (Björdal 2012; Broda et al. 2019). Moreover, owing to the degradation, when the waterlogged wood dries, it not only shrinks due to the formation of new hydrogen bonds between the chains of the cell wall polymers resulting from the removal of water molecules, as happens when any kind of wood dries, but additionally, its weakened, degraded cell walls tend to collapse due to capillary forces and the high surface tension of evaporating water, which leads to further modifications in its structure (Christensen et al. 2006; Jiachang et al. 2009; Redman et al. 2016; Nguyen et al. 2018). All this, in turn, translates into alterations in wood permeability, as well as moisture and mechanical behaviour (Esteban et al. 2010; Guo et al. 2018; Welling et al. 2018; Broda et al. 2019). Drying then is a key factor affecting further wood properties.

Drying process creates a specific moisture gradient inside wood, since its external layers dry more rapidly than the internal ones. Once the moisture content in the outer parts decreases below the fibre saturation point, the wood starts to shrink. However, because the inner layers remain saturated, the shrinkage of external areas is hampered, which generates internal stresses in wood. As a result, when the stresses exceed the mechanical strength of the material, the wood starts to crack and split. To prevent the formation of defects, the proper balance in moisture movement throughout the wood tissue must be maintained upon the whole drying process (Redman et al. 2016).

In the case of sound wood intended for industrial purposes, the applied drying method should ensure the appropriate moisture content with the highest wood quality (lack of defects) in the fastest time whilst being cost-effective. Amongst the most frequently used industrial drying processes are kiln drying and vacuum drying (for hardwood) (Perre and Keey 2006; Redman et al. 2016, 2017). As for waterlogged archaeological wood, however, although the purpose and general principles of drying are similar to commercial wood, the overarching goal is to remove water whilst keeping the structural integrity and appearance (shape and dimensions) of wooden artefact unaffected. Therefore, maintaining of freshly excavated waterlogged objects often involves not only safe removal of water molecules but also replacing it with appropriate conservation agent to ensure dimensional stabilisation of wood. The most common drying methods of waterlogged wood include freeze-drying (combined with a polyethylene glycol treatment) or air-drying after replacing water with a solvent with lower surface tension to limit the shrinkage of the object (McKerrell et al. 1972; Grattan and McCawley 1978; Grattan 1987; Ambrose 1989, 1990; Perre and Keey 2006). 
Since waterlogged archaeological wooden objects usually constitute priceless artefacts of cultural heritage, understanding the complex interactions between the wood ultrastructure and the resulting properties on a molecular level is necessary to ensure their proper conservation/reconservation and protection to preserve them for posterity. Hence, this is the aim of the present study, with a particular emphasis on the influence of drying conditions on the relations between the cell wall structure, dimensional stability and hygroscopicity of degraded archaeological wood.

\section{Materials and methods}

\section{Materials}

Waterlogged archaeological elm (Ulmus spp.), excavated from debris of the mediaeval "Poznań" bridge at the bottom of the Lednica Lake (the Wielkopolska Region, Poland), was used for the study. The elm log consisted only of heartwood, and although apparently well-preserved in appearance, it proved to be severely degraded, with the loss of wood substance (LWS) estimated at 70-80\% and significantly reduced hemicelluloses and cellulose content (Broda et al. 2020; Spear and Broda 2020).

\section{Methods}

\section{Sample preparation}

To perform the planned measurements, small rectangular samples $(20 \mathrm{~mm} \times 20$ $\mathrm{mm} \times 10 \mathrm{~mm}$ in the radial (R), tangential (T), and longitudinal (L) directions) were cut out from waterlogged archaeological elm. Waterlogged samples were then dried using different drying methods, as shown in Table 1. Amongst the drying techniques

Table 1 Drying methods applied to waterlogged wood samples

\begin{tabular}{|c|c|c|}
\hline Sample ID & Drying method & The method description \\
\hline $\mathrm{AD}$ & Air-dried & $\begin{array}{l}\text { 1. Air-drying at room temperature (about } 23-25^{\circ} \mathrm{C} \text { ) for two } \\
\text { weeks }\end{array}$ \\
\hline OD_50 & Oven-dried at $50{ }^{\circ} \mathrm{C}$ & 1. Oven-drying at $50{ }^{\circ} \mathrm{C}$ for one week \\
\hline OD_104 & Oven-dried at $104{ }^{\circ} \mathrm{C}$ & 1. Oven-drying at $104{ }^{\circ} \mathrm{C}$ for one week \\
\hline FD & Freeze-dried & 1. Freeze-drying \\
\hline $\mathrm{CP}$ & $\begin{array}{l}\text { Solvent exchanged, dried at } \\
\mathrm{CO}_{2} \text { critical point }\end{array}$ & $\begin{array}{l}\text { 1. Dehydration with } 96 \% \text { ethanol for four weeks } \\
\text { 2. Solvent change from ethanol to acetone for } 3 \text { days } \\
\text { 3. } \mathrm{CO}_{2} \text { critical point drying using an E3000 Series Critical } \\
\text { Point Dryer (Quorum Technologies LTD, UK) }\end{array}$ \\
\hline SC_AD & Solvent exchanged, air-dried & $\begin{array}{l}\text { 1. Dehydration with } 96 \% \text { ethanol for four weeks } \\
\text { 2. Solvent change from ethanol to acetone for } 3 \text { days } \\
\text { 3. Air-drying in a fume hood at room temperature }\left(23-25^{\circ} \mathrm{C}\right) \\
\text { for one week }\end{array}$ \\
\hline
\end{tabular}


selected for the research, there are methods known for their excellent efficiency in the preservation of the wood structure, such as the supercritical $\mathrm{CO}_{2}$ drying (CP) which generally does not induce collapse or internal checking (Kaye et al. 2000; Dawson and Pearson 2017; Dawson et al. 2020), and freeze-drying (FD) which due to the sublimation (evaporation directly from a solid state without transition to a liquid state) of water from wood cells does not cause pit aspiration, thus limits capillary tension and the resulting collapse (Grattan and McCawley 1978; Jian-xiong et al. 2005; Perre and Keey 2006). Similarly, a change of solvent from water to acetone (SC_AD) was applied to limit surface tension, and thus limit collapse during air-drying (Perre and Keey 2006). Air-drying was used as the simplest method for wood drying (AD), whilst oven-drying at different temperatures (OD_50 and OD_104, respectively) was selected for comparison as the methods which result in the most pronounced shrinkage and collapse owing to the highest stresses induced in wood during drying (Perre and Keey 2006).

\section{Shrinkage calculations}

The dimensions of wet and dry samples in all the three anatomical directions (5 measurements along each edge) were measured using a digital calliper with an accuracy of $0.01 \mathrm{~mm}$. Then, the volumetric shrinkage of the samples was calculated based on their dimensions before and after drying. Five replicates of each variant were used for the measurements. Although the applied method is not of the highest precision, it was sufficient enough to compare shrinkage of wood differing in the drying methods applied.

\section{Surface area and pore volume measurements}

A Gemini Surface Area Analyser (Micromeritics Instrument Corporation, Georgia, USA) and a nitrogen absorption method were applied to characterise porosity of waterlogged wood dried with different methods. Prior to the analysis, the samples were de-gassed carefully to avoid any alterations of the cell wall structure. The nitrogen adsorption-desorption isotherms were recorded at liquid nitrogen temperature. There was a difference in the time required for analysis with critical point- and freeze-dried specimens in particular taking an extended time (7-8 h compared to the other samples 3-4 h). This therefore required that the nitrogen dewar was refilled at regular intervals without interrupting the analysis. Following the Brunauer-Emmett-Teller (BET) theory (Brunauer et al. 1938), the surface area for each sample was calculated based on the volume of $\mathrm{N}_{2}$ absorbed at different partial pressures using Micromeritics Stardriver software. Wood porosity was characterised according to the Barrett-Joyner-Halenda (BJH) method (Barrett et al. 1951).

\section{Sorption analyses}

Wood moisture properties were characterised using a dynamic vapour sorption (DVS) advantage system (Surface Measurement Systems, London, UK). The measurements were performed at a constant temperature of $21{ }^{\circ} \mathrm{C} \pm 0.2{ }^{\circ} \mathrm{C}$ with a flow 
rate of nitrogen passing over the sample adjusted to $200 \mathrm{~cm}^{3} \mathrm{~s}^{-1}$. About $10 \mathrm{mg}$ of wood powder from each wood type and drying variant was analysed. The equipment was programmed to start at $0 \%$ of air relative humidity $(\mathrm{RH})$ and then increased in $5 \%$-steps up to $95 \% \mathrm{RH}$ for the adsorption phase, and conversely for the desorption phase. The sample was maintained at a constant RH until the equilibrium was reached, i.e. the ratio of change in mass to change in time was less than $0.002 \%$ per minute for at least $10 \mathrm{~min}$. It has been shown that much longer hold times of the equilibrium change over point produce slightly different final moisture content values (Glass et al. 2018). However, for this study, the stated equilibrium point was selected as a good compromise between the reasonable analysis test length and the ultimate final moisture content accuracy. The integral humidity and temperature probes situated near the sample monitored the actual conditions inside the DVS chamber. The data such as running time, target and actual $\mathrm{RH}$, and mass change were recorded every $20 \mathrm{~s}$ and then used in the analysis of the isotherms obtained. Two sorption cycles were run for each sample for the detailed moisture sorption characteristics.

\section{Hydroxyls accessibility measurements}

The accessibility of the hydroxyl groups was analysed using a method utilising deuterium exchange in the DVS apparatus (Lee et al. 2011; Rautkari et al. 2013). Instead of water, the DVS reservoir was filled with $\mathrm{D}_{2} \mathrm{O}$. Approximately 10-20 mg of milled wood particles was placed in the sample pan, and it was preconditioned at $0 \% \mathrm{RH}$ of deuterium oxide $\left(\mathrm{D}_{2} \mathrm{O}\right)$ and nitrogen (flow rate $200 \mathrm{~cm}^{3} \mathrm{~s}^{-1}$ ) at a temperature of $21{ }^{\circ} \mathrm{C}$ to remove any adsorbed water molecules. Six adsorption-desorption (RH 0-90\%) cycles were conducted, and the dry mass increase due to deuterium exchange was calculated. The DVS apparatus maintained a constant RH until the sample moisture content change per minute $(\mathrm{dm} / \mathrm{dt})$ was less than $0.002 \%$ per minute over a 10-min period to ensure the equilibrium in each $\mathrm{RH}$ step. Hydroxyls accessibility was calculated from the difference between the initial dry weight of the sample and the dry weight after the final cycle, which finished based on the endpoint criterion noted above. Three replicates of each variant were measured, with mean and standard deviation values determined.

\section{Statistical analyses}

Principal component analysis (PCA) is a multivariate statistical technique used for extraction and interpretation of the systematic variance in a data set. This analysis replaces a complex multi-dimensional data set with a simplified one, which allows for understanding relations between particular properties of the analysed objects (Jackson 2005). In this study, PCA was performed on the set of data obtained for waterlogged elm samples dried with different methods to highlight the similarities and differences between them, as well as to help understand relations between the structure of the cell wall and its moisture properties depending on the drying method. First, two data groups, i.e. the cell wall characteristics (Table 2) and the 
Table 2 Mean values of surface area, total pore volume and volumetric shrinkage of waterlogged archaeological elm wood dried with different methods

\begin{tabular}{lclc}
\hline Wood ID & Surface area $\left(\mathrm{m}^{2} \mathrm{~g}^{-1}\right)$ & $\begin{array}{l}\text { Total pore } \\
\text { volume }\left(\mathrm{cm}^{3}\right. \\
\left.\mathrm{g}^{-1}\right)\end{array}$ & Shrinkage $(\%)$ \\
\hline AD & $1.60 \pm 0.08$ & 0.0038 & $68.31 \pm 3.39$ \\
OD_50 & $5.06 \pm 0.05$ & 0.0209 & $39.78 \pm 5.13$ \\
OD_104 & $0.67 \pm 0.06$ & 0.0022 & $65.19 \pm 9.80$ \\
FD & $21.78 \pm 1.78$ & 0.1562 & $7.55 \pm 1.94$ \\
CP & $32.81 \pm 1.77$ & 0.2263 & $8.78 \pm 1.38$ \\
SC_AD & $3.63 \pm 0.33$ & 0.0114 & $21.65 \pm 3.02$ \\
\hline
\end{tabular}

$A D$ air-dried, $O D \_50$ oven-dried at $50{ }^{\circ} \mathrm{C}, O D \_104$ oven-dried at $104{ }^{\circ} \mathrm{C}, F D$ freeze-dried, $C P$ dried at $\mathrm{CO}_{2}$ critical point, $S C \_A D$ solvent changed and air-dried, $C E$ contemporary elm

moisture properties parameters (Table 3) were considered separately in the calculations to study the specific influence of the drying method on the features inside the groups and clarify the interdependencies between them. Finally, the PCA was performed on the complete data set to show the whole picture of interactions between the analysed wood properties in relation to the drying method applied.

STATISTICA 13.3.0 software (TIBCO Software Inc., Palo Alto, CA, USA) was used for the PCA calculations.

\section{Results and discussion}

\section{Wood shrinkage and the cell wall characteristics}

Application of different drying methods onto waterlogged elm wood resulted in a different level of its shrinkage. As expected, the highest contraction, reaching over $65 \%$, was observed when wood was subjected to air-drying or oven-drying at 104 ${ }^{\circ} \mathrm{C}$ (Table 2). In turn, freeze-drying and drying at $\mathrm{CO}_{2}$ critical point (supercritical drying) proved to be the most efficient methods that stabilise wood dimensions and resulted in the volumetric wood shrinkage not exceeding $10 \%$. Intermediate shrinkage values of about $40 \%$ and $22 \%$ were noted for wood oven-dried at $50{ }^{\circ} \mathrm{C}$ and airdried after a solvent exchange, respectively.

The degree of shrinkage reflects changes in wood anatomical structure that arose during drying. The results of the cell wall area measurements (Table 2) clearly show that the highest values were obtained for the less shrunken wood dried at $\mathrm{CO}_{2}$ critical point and freeze-dried (32.8 and $21.8 \mathrm{~m}^{2} \mathrm{~g}^{-1}$, respectively), whilst the lowestfor the most constricted oven-dried at $104{ }^{\circ} \mathrm{C}$ and air-dried samples (0.7 and 1.6 $\left.\mathrm{m}^{2} \mathrm{~g}^{-1}\right)$. Again, intermediate values were noted for OD_50 and SC_AD samples. An inverse correlation was found between wood shrinkage and the corresponding surface area of the cell walls (Fig. 1a) - the higher the shrinkage, the smaller the surface area is. In turn, the surface area of the cell wall is correlated with a total pore 
volume of pores existing in the cell wall (Fig. 1b, Table 2) - the larger the surface area, the higher the total pore volume is.

More detailed characteristics of pore size and distribution in the cell walls of waterlogged wood dried with different methods are presented in Figs. 2 and 3. Generally in the wood structure, three pore size classes can be identified: micropores $(<2 \mathrm{~nm})$, mesopores $(2-50 \mathrm{~nm})$ and macropores $(>50 \mathrm{~nm})$ (Kimura et al. 2016; Ormondroyd et al. 2017). Although the nitrogen absorption method does not give reliable results for micro- and the smallest mesopores (with the diameter below 4 $\mathrm{nm}$ ) due to the properties of nitrogen, as described before (Broda et al. 2019), it is still applicable to making comparisons between the tested specimens.

It is clear from Fig. 2 that in the analysed wood, irrespective of the drying method applied, the majority of pores present were micropores and small mesopores, which is typical for wood structure (Kojiro et al. 2010; Yin et al. 2015). However, depending on the drying method used, different conditions of the pores could be determined. The data for the oven- and air-dried samples (Fig. 2a) appear to show the micro/small mesoporous structure, without any clear definitive pore size. This is in stark contrast to the distribution seen with the critical point- and freeze-dried samples (Fig. 2b, c). These show clear peaks in the $15 \mathrm{~nm} \pm 3 \mathrm{~nm}$ range. This would appear to be a truer representation of the actual pore structure of the wood, which is supported by the cumulative volume data presented in Fig. 3, where the large increase in sorption volume by the pores in the $15 \mathrm{~nm}$ range in the critical point/ freeze-dried samples can be seen. No such increase is shown in the air/oven-dried samples. Indeed, when the combined values of shrinkage, surface area and pore distribution data of the freeze/supercritical-dried samples are compared to the air- and oven-dried samples, it can be concluded that the oven/air-dried samples have a very collapsed pore structure, whilst the critical point- and freeze-dried samples retain the open porous structure typical for wood. The differences in the cell wall structure between supercritical- and freeze-dried wood result from the nature of the drying process. During freeze-drying, the water present in the FD samples freezes and forms small ice crystals which may cause some damage to the weakened cell walls (Kaye et al. 2000; Jian-xiong et al. 2005), hence the greater fraction of bigger pores and the smaller surface area in comparison with CP samples.

At a macro-scale, surface tension effects of removing water cause collapse of the wood structure, especially if it has been degraded, such as with archaeological wood. Drying from a wet solvent (acetone) state reduces surface tension effects, whilst freeze-drying and critical point drying remove the effects caused by surface tension resulting in the least shrinkage (Grattan and McCawley 1978; Kaye et al. 2000; Perre and Keey 2006; Dawson and Pearson 2017; Dawson et al. 2020). Figure 4 of the PCA plot (variance explained by a principal component was $99.9 \%$ ) shows the close similarity of the OD_104 and air-dried samples, suggesting that fast high-temperature drying has similar effects to slow lower temperature (room temperature) drying, whilst drying at a moderate speed and intermediate temperature, i.e. oven-drying at $50{ }^{\circ} \mathrm{C}$, seems a little bit different (more beneficial at reducing shrinkage). Looking at the cell wall scale, at elevated temperatures and in the presence of moisture, wood cell wall lignin and hemicellulose matrix polymers become softened (Engelund et al. 2013; Thybring et al. 2017). In particular, lignin becomes 


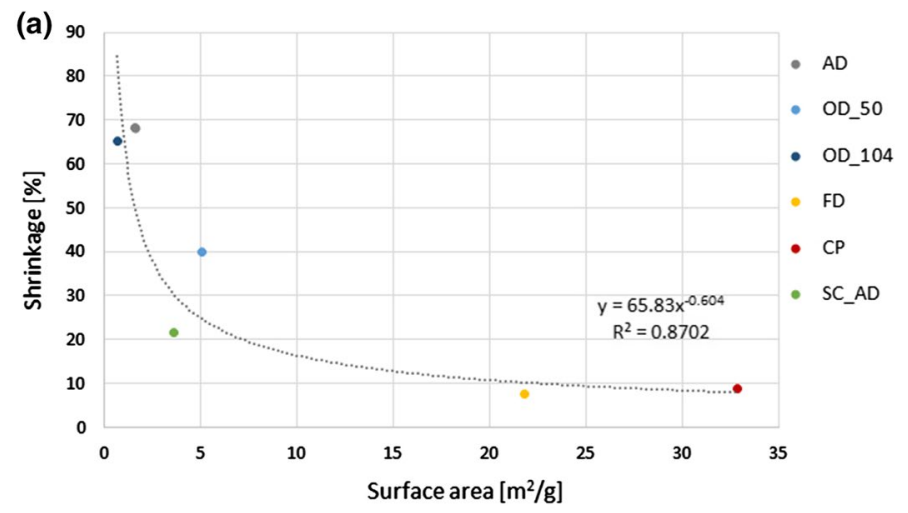

(b)

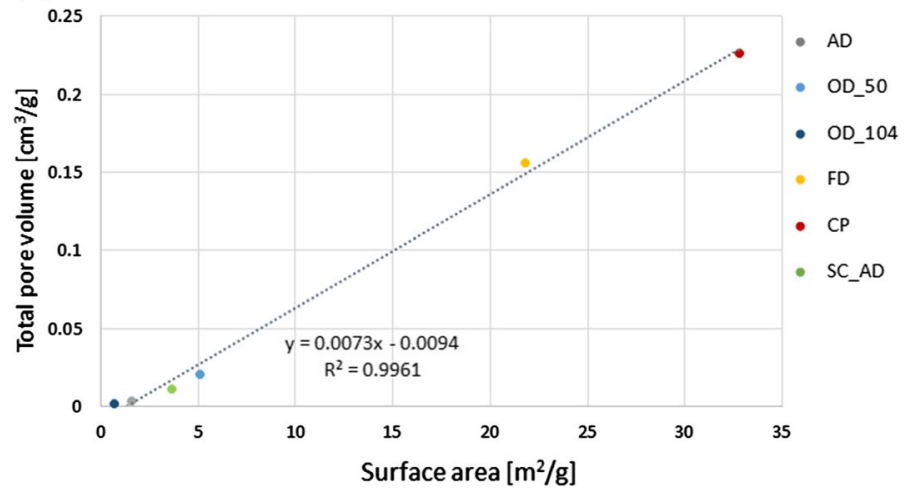

Fig. 1 Correlation between shrinkage and the cell wall surface area (a), and between the cell wall surface area and the total pore volume (b) of waterlogged archaeological wood dried with different methods

softer above 60 to $70{ }^{\circ} \mathrm{C}$, whilst hemicellulose can soften at $60{ }^{\circ} \mathrm{C}$ given sufficient moisture. As the wood dries, there may be a reorganisation of the polymer structure (Thybring et al. 2017) in the softened and wet conditions. Thybring suggests that at high temperature the drying is too fast for adequate polymeric reorganisation, whilst at low temperature, the moisture content is not high enough for long enough for the same reorganisation. However, at the intermediate temperatures, there may be an optimum point when this reorganisation can occur. The present surface area and porosity data appear to give some support to this hypothesis. However, in the case of these samples with reduced hemicelluloses content, and therefore an increased relative lignin content, the observed effect may be mainly due to changes in the lignin structure (e.g. Kojiro et al. (2010) suggest that microstructure of the cell wall depends on the lignin structure, including the degree of its condensation and internal cross-linking). In this model, it is possible that the speed and temperatures involved in freeze and supercritical drying prevent any matrix reorganisation and maintain the pore structure. The distinction of the group consisting of CP and FD samples is clearly visible in the PCA plot (Fig. 4). It confirms structural similarities 

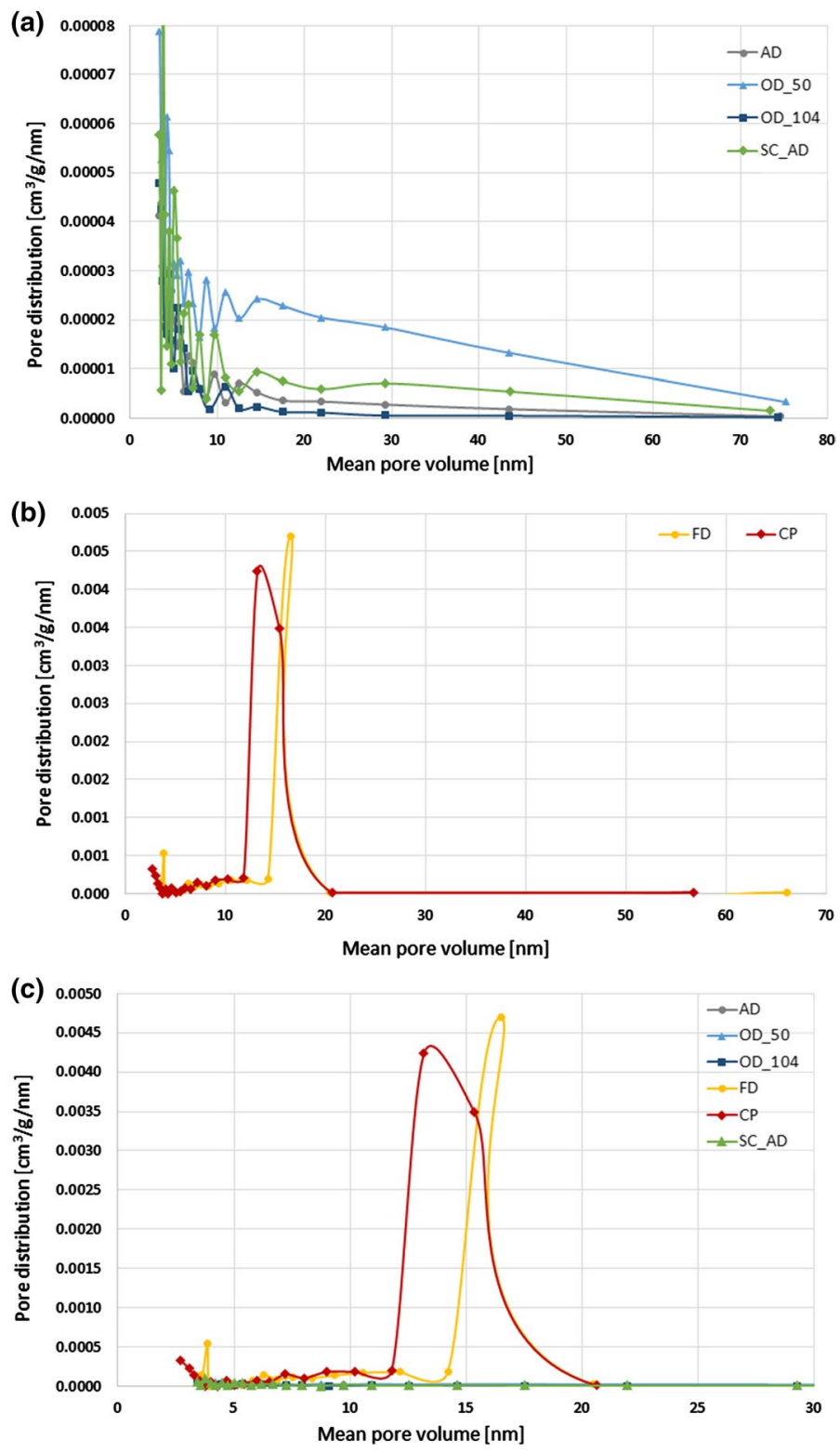

Fig. 2 Pore distribution as a function of the pore volume illustrating the different distribution types of waterlogged archaeological elm wood dried with different methods (a pore distribution for air-dried and oven-dried wood samples, b pore distribution for freeze-dried and supercritical-dried samples, c comparison of pore distribution for wood samples dried with all methods applied in the study)

between the two samples together with their divergence from the rest of the tested specimens. The analysis also clearly distinguishes the structural difference of the SC_AD sample. 


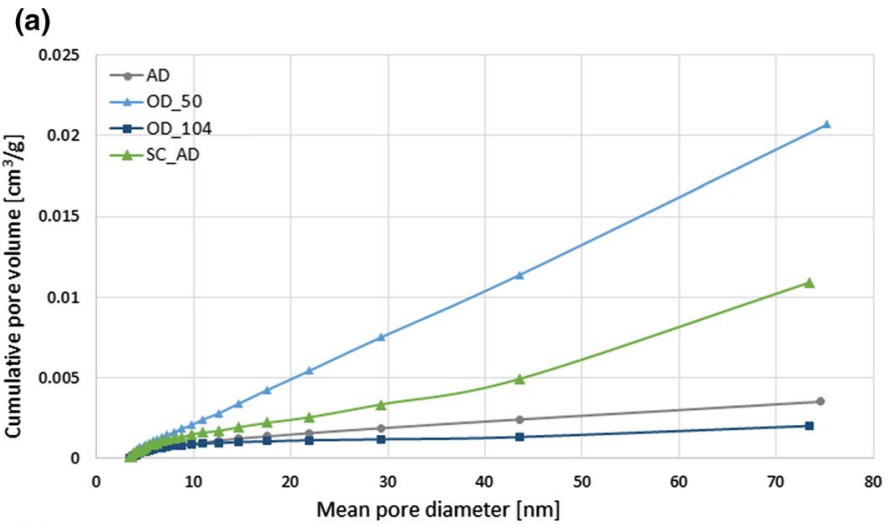

(b)

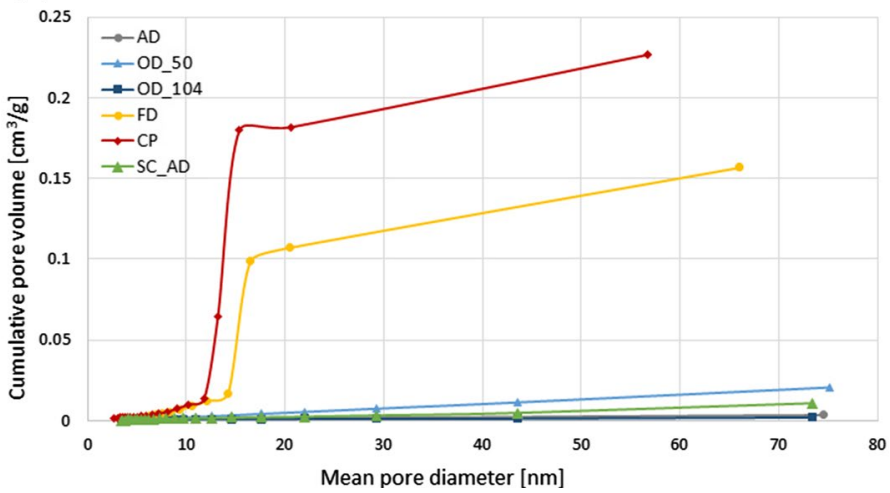

Fig. 3 Cumulative pore volume as a function of the pore radius illustrating the different distribution types of waterlogged archaeological elm wood dried with different methods (a cumulative pore volume for air-dried and oven-dried wood samples, $\mathbf{b}$ comparison of cumulative pore volume for wood samples dried with all methods applied in the study)

\section{Sorption properties}

Figure 5 presents sorption isotherms plotted as equilibrium moisture content (EMC) against RH over two sorption cycles for waterlogged archaeological elm dried with different methods (5A and 5B). The related absolute hysteresis, typical for wood and other porous materials (Fredriksson and Thybring 2019), obtained by subtracting the adsorption EMC from the desorption EMC values are presented in Fig. 5c, d. In all cases, differences in sorption isotherms between the first and the second cycle were observed, although exact differences varied for each sample type as discussed below. This may indicate a change in the wood between the first and second cycle, which appears to be affected by the drying process used. It is possible that the humidity step equilibrium end conditions do not give the ultimate equilibrium point, as stated previously (Glass et al. 2018), due to differences in the rate of change in mass. However, in this case, the observed differences still indicate variations between both the drying methods and the first and second cycles. 
For elm oven-dried at $104{ }^{\circ} \mathrm{C}$ (OD_104), desorption curves in both cycles were almost reproducible, whilst in adsorption part, EMC values were substantially higher in the second cycle; EMC max values were almost the same for both cycles (Table 3). Maximum hysteresis for both cycles was seen at about $62.7-62.8 \% \mathrm{RH}$, with a decrease by $1.58 \%$ in the second run (Table 3 ).

With air-dried (AD) and oven-dried at $50{ }^{\circ} \mathrm{C}$ (OD_50) samples, the desorption branches of the isotherms in both cycles were similar, with EMC values only slightly lower in the second cycle in the upper part of the hygroscopic range. There were substantial differences in the adsorption curves between the first and the second cycle, with EMC values higher in the latter. EMC max values were lower in the second cycle by 0.48 and $0.64 \%$, respectively (Table 3 ). A decrease in the second run hysteresis was slightly lower than for OD_104, and for the air-dried sample the maximum hysteresis was shifted to a higher $\mathrm{RH}$ of $70 \%$ in both runs.

The drying of waterlogged elm at $\mathrm{CO}_{2}$ critical point $(\mathrm{CP})$ resulted in quite similar isotherms for both cycles, with EMC values only slightly higher in the lower part of the hygroscopic range and slightly lower in its upper part in the desorption curve of the second cycle, and EMC values slightly higher in the middle part of the adsorption curve for the second cycle. EMC max was lower in the second cycle by $0.65 \%$.

Similar moisture behaviour was observed for air-dried after a solvent exchange (SC_AD) and freeze-dried (FD) elm samples. The adsorption branches of the isotherms were almost reproducible for both cycles. The desorption parts were also similar, with EMC values only slightly lower in the upper part of the hygroscopic range in the second cycle. Although, in the case of SC_AD, EMC max and the difference in EMC max between the first and the second run were lower than for FD (Table 3).

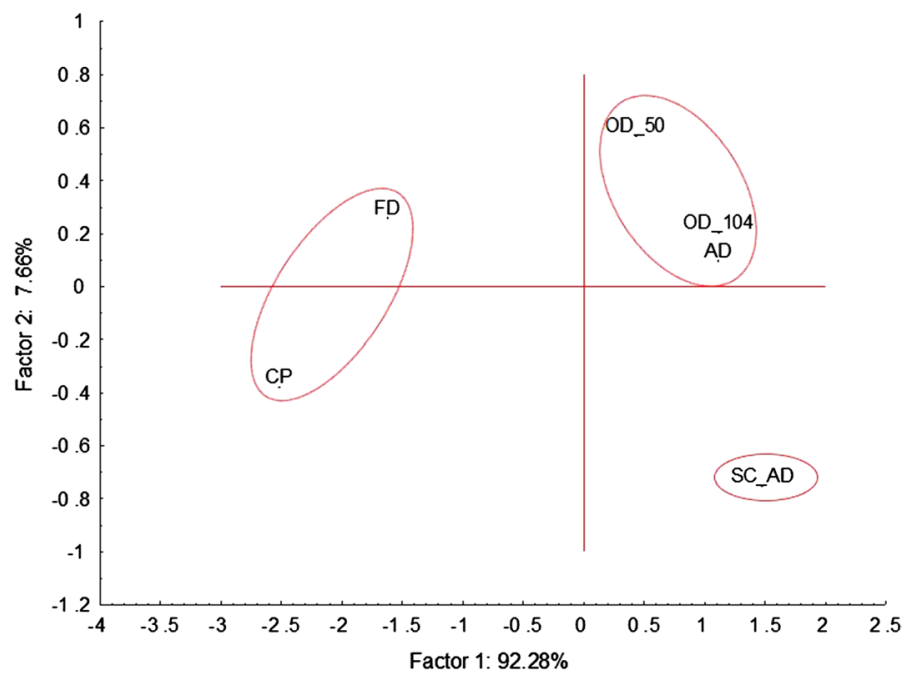

Fig. 4 Principal component analysis regarding cell wall structure of the studied waterlogged elm samples dried with different methods-PC1 versus PC2 score plots 
Table 3 Mean values of free hydroxyls, values of maximum hysteresis (maximum difference of EMC between desorption and adsorption) in the first run ( $\mathrm{H} 1 \mathrm{max})$, maximum hysteresis in the second run ( $\mathrm{H} 2 \mathrm{max}$ ), corresponding air relative humidity ( $\mathrm{RH} 1$ and $\mathrm{RH} 2$, respectively), the difference in max hysteresis between the first and the second run ( $\triangle \mathrm{Hmax})$, maximum EMC in the first (EMC1) and the second (EMC2) run, respectively, and the difference in maximum EMC between the first and the second run $(\triangle \mathrm{EMC})$ for waterlogged archaeological elm wood dried with different methods

\begin{tabular}{lcllllllll}
\hline $\begin{array}{l}\text { Wood } \\
\text { ID }\end{array}$ & $\begin{array}{l}\text { Hydroxyls } \\
\left(\mathrm{mmol} \mathrm{g}^{-1}\right)\end{array}$ & $\begin{array}{l}\mathrm{H} 1 \mathrm{max} \\
(\%)\end{array}$ & $\begin{array}{l}\text { RH1 } \\
(\%)\end{array}$ & $\begin{array}{l}\mathrm{H} 2 \mathrm{max} \\
(\%)\end{array}$ & $\begin{array}{l}\text { RH2 } \\
(\%)\end{array}$ & $\begin{array}{l}\Delta \text { Hmax } \\
(\%)\end{array}$ & $\begin{array}{l}\text { EMC1 } \\
(\%)\end{array}$ & $\begin{array}{l}\text { EMC2 } \\
(\%)\end{array}$ & $\begin{array}{l}\Delta \mathrm{EMC} \\
(\%)\end{array}$ \\
\hline $\mathrm{AD}$ & $5.89 \pm 1.42$ & 4.93 & 70 & 3.61 & 70 & 1.32 & 20.17 & 19.69 & 0.48 \\
OD_50 & $7.72 \pm 0.39$ & 4.93 & 62.8 & 3.78 & 62.6 & 1.15 & 22.31 & 21.67 & 0.64 \\
OD_104 & $6.18 \pm 1.89$ & 4.85 & 62.7 & 3.27 & 62.8 & 1.58 & 17.33 & 17.24 & 0.09 \\
FD & $10.15 \pm 0.88$ & 3.76 & 70 & 3.28 & 70 & 0.48 & 20.50 & 19.83 & 0.67 \\
CP & $7.23 \pm 2.00$ & 3.81 & 70 & 3.02 & 60 & 0.79 & 18.19 & 17.54 & 0.65 \\
SC_AD & $9.56 \pm 0.34$ & 3.69 & 70 & 3.29 & 70 & 0.40 & 19.59 & 19.18 & 0.41 \\
\hline
\end{tabular}

$A D$ air-dried, $O D \_50$ oven-dried at $50{ }^{\circ} \mathrm{C}, O D \_104$ oven-dried at $104{ }^{\circ} \mathrm{C}, F D$ freeze-dried, $C P$ dried at $\mathrm{CO}_{2}$ critical point, $S C \_A D$ solvent changed and air-dried, $C E$ contemporary elm

With FD, CP and SC_AD specimens, hysteresis in the first cycle was significantly lower than for oven- and air-dried samples. Moreover, for these specimens, an observed decrease in hysteresis in the second cycle was significantly lower than for AD, OD_50 and OD_104 samples. Interestingly, for CP, the maximum hysteresis was additionally shifted from 70 to $60 \%$ RH (Fig. 5c, d, Table 3). For air- and oven-dried samples, the differences in hysteresis appear to be caused by differences in the sorption stage in cycles 1 and 2 . The first cycle seems to cause a rewetting and partial "reopening" of the pore structure, which then remains relatively open during the first desorption stage. During the second stage, the more open structure allows for higher moisture content during the sorption stage. In contrast with the freeze-, supercritical- and solvent exchanged air-dried samples, the pore structure is more fully open during the first cycle, and there is a significant difference in hysteresis shown with these three methods. It is surprising considering the fact that these samples are the most shrunken ones, where the cell wall seemed to not only shrink but also collapse. The ability of the structure to reopen, though, questions the idea of hornification of the cell wall polymers on drying, especially in the case of drying at elevated temperatures (OD_50, OD_104), when the degree of cellulose microfibril aggregation increases, which should result in increasing the degree of hornification (Diniz et al. 2004; Salmén and Stevanic 2018). The possibility is that in this case, hornification is reduced due to the degraded state of the material with a reduction in hemicelluloses content. However, in the case of FD, CP and SC_AD, despite the same lower hemicelluloses content, the much lower hysteresis can be seen. It may suggest that, although the structure of those wood samples is more porous (Table 2), the inter- and intramolecular bonding of wood polymers in the cell wall is stronger and more stable and/or the mechanical resistance of the cell walls is higher than in 
Fig. 5 Water sorption isotherms (a, b) and hysteresis (c, d) for waterlogged archaeological elm wood dried with different methods; ads adsorption, des desorption
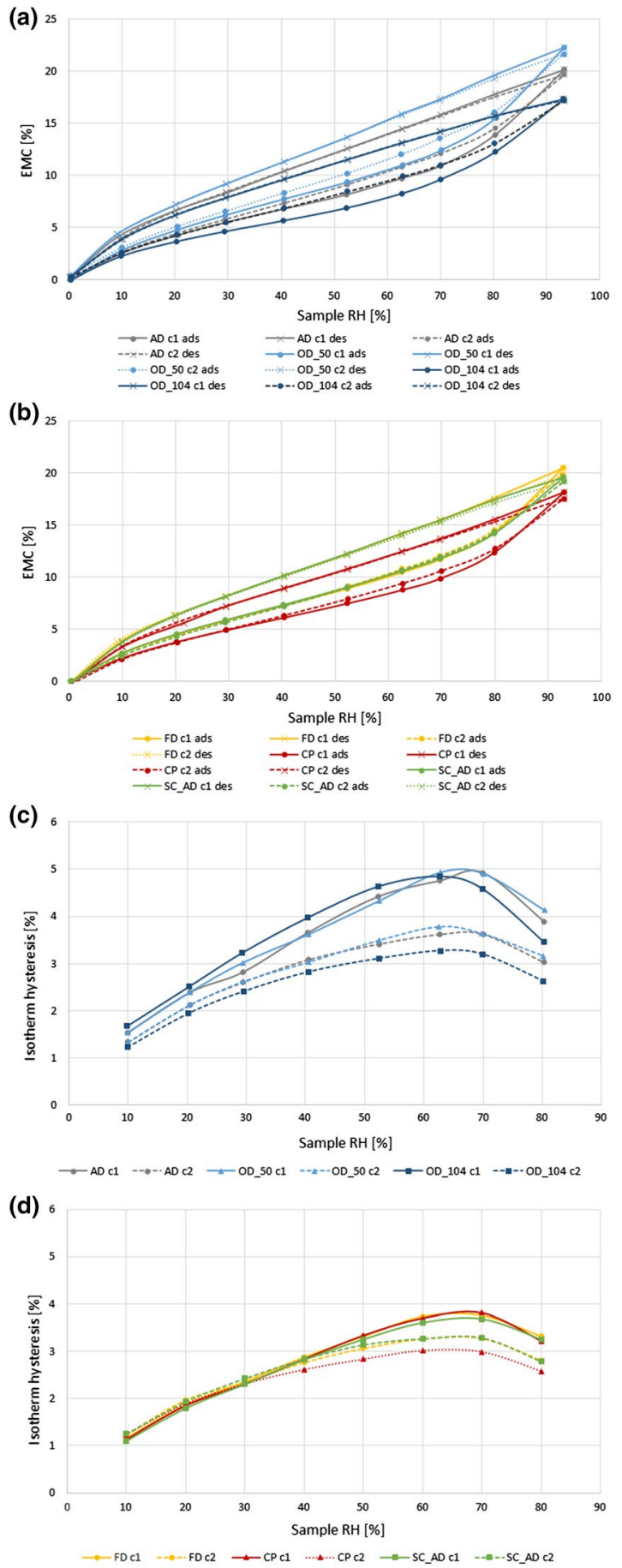
the case of collapsed cell walls of air- and oven-dried samples (Broda et al. 2019), which results in better stabilisation of the structure, thus more even water sorption in both cycles.

As clearly shown in Table 3, the accessibility of the cell wall hydroxyl groups to deuteration in the form of water vapour depends on the drying method applied. The highest hydroxyls availability was obtained for FD and SC_AD samples (10.15 and $9.56 \mathrm{mmol} \mathrm{g}^{-1}$, respectively), the lowest for AD and OD_104 specimens (5.89 and $6.18 \mathrm{mmol} \mathrm{g}^{-1}$, respectively). The effect of drying conditions on hydroxyls availability was also shown by Thybring et al. (2017), who found out that vacuum drying of sound Norway spruce sapwood at $60{ }^{\circ} \mathrm{C}$ for 3 days reduced the accessibility of the cell wall hydroxyls to deuteration by water vapour more than drying for 1 day at 103 ${ }^{\circ} \mathrm{C}$ without vacuum. In the present case, a vacuum was used at much lower temperatures during freeze-drying, and apparently it has no reducing effect on hydroxyls availability.

Considering the results of PCA analysis (variance explained by a principal component was $79.95 \%$ ) of the tested samples in relation to their moisture properties (DVS and -OH availability data) (Fig. 6b), a slightly different picture can be seen in comparison with the PCA results for wood structural properties (Fig. 4). FD and CP samples are grouped together with the SC_AD one (the last one was separated as different with regard to structural properties). The close proximity of the FD and SC_AD suggests high similarity in their moisture properties. AD is grouped with OD_50 (similar properties), whilst OD_104 is separated from the others - the PCA analysis based on structural data grouped AD with OD_104, whilst OD_50 was slightly different. These results clearly show that moisture properties of degraded wood dried with different methods are not solely related to its microstructure, and that some other factors affect them (e.g. changes in wood polymers due to elevated temperature applied during drying).

From the representation of variables in the space of the first two principal components (Fig. 6a), the correlations between EMC1 and EMC2, RH2, and $\triangle \mathrm{EMC}$, and the number of hydroxyls and RH1 or RH2 are visible, as well as a strong negative correlation between the number of hydroxyls available and the difference of max hysteresis between the first and the second DVS run. No correlation between the number of hydroxyls and EMC exists.

The results of the PCA analysis of the tested samples in relation to both their structural and sorption properties are presented in Fig. 7. According to this, four different groups of samples can be distinguished, depending on the applied drying method: OD_104, AD with OD_50, FD with SC_AD and CP. The representation of variables in the space of the first two principal components (Fig. 7a) confirms the previously described correlations between particular structural properties and particular sorption parameters. Surprisingly, it shows no correlation between structural parameters and the number of free hydroxyls or EMC, which indicates the more complex nature of the interactions between wood sorption properties and microstructure in respect of the applied drying methods. 


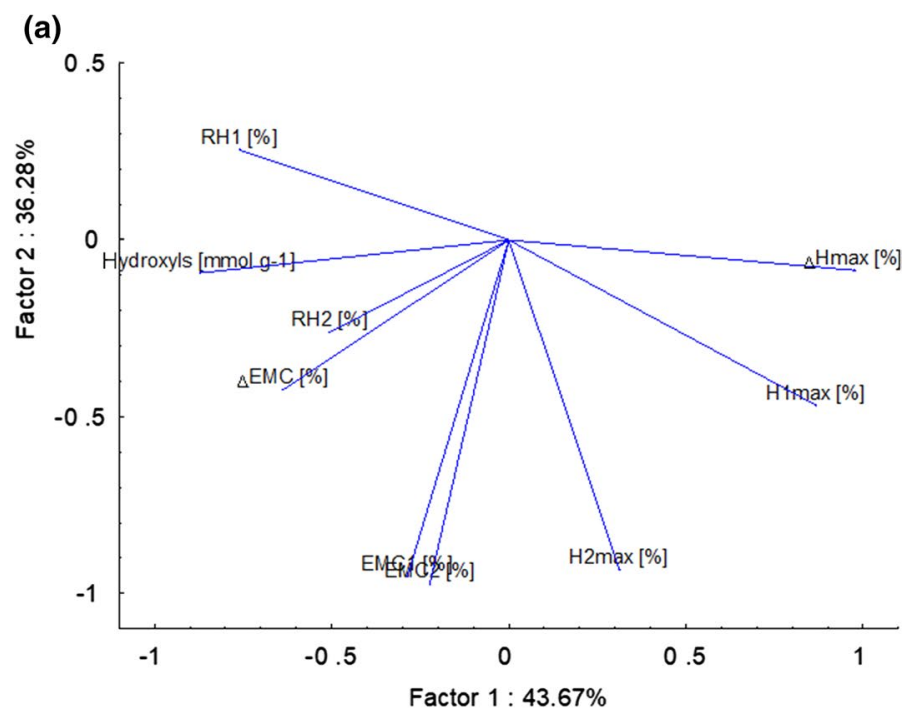

(b)

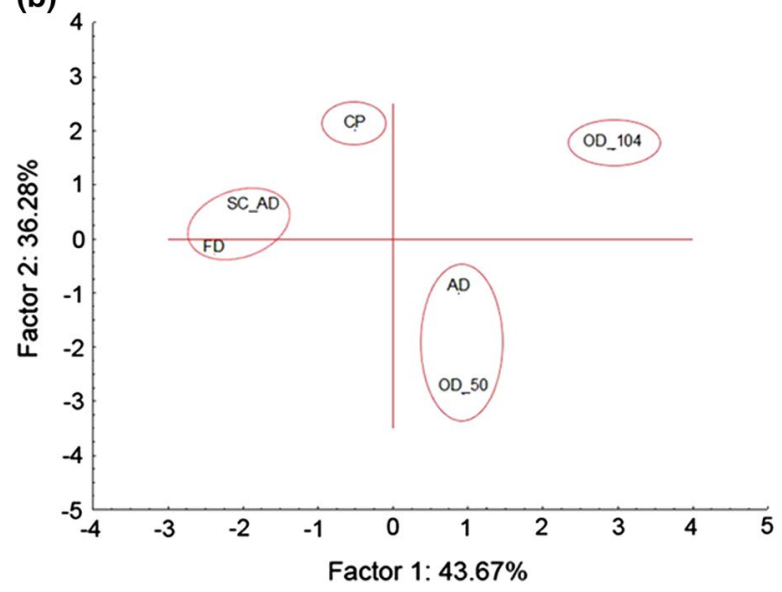

Fig. 6 Principal component analysis regarding sorption properties and hydroxyl availability of the cell wall of the studied waterlogged elm samples dried with different methods: a Representation of variables in the space of the first two principal components; b PC1 versus PC2 score plots

\section{Conclusion}

The results of the presented research clearly show that depending on the drying method applied to highly degraded waterlogged archaeological wood, the resulting material differs significantly in structure, dimensions and sorption properties. Air- and oven-drying generally resulted in the highest wood shrinkage, lower porosity, as well as a decreased number of free hydroxyls in the wood cell wall, suggesting formation of strong intra- and intermolecular interactions in the collapsed state 


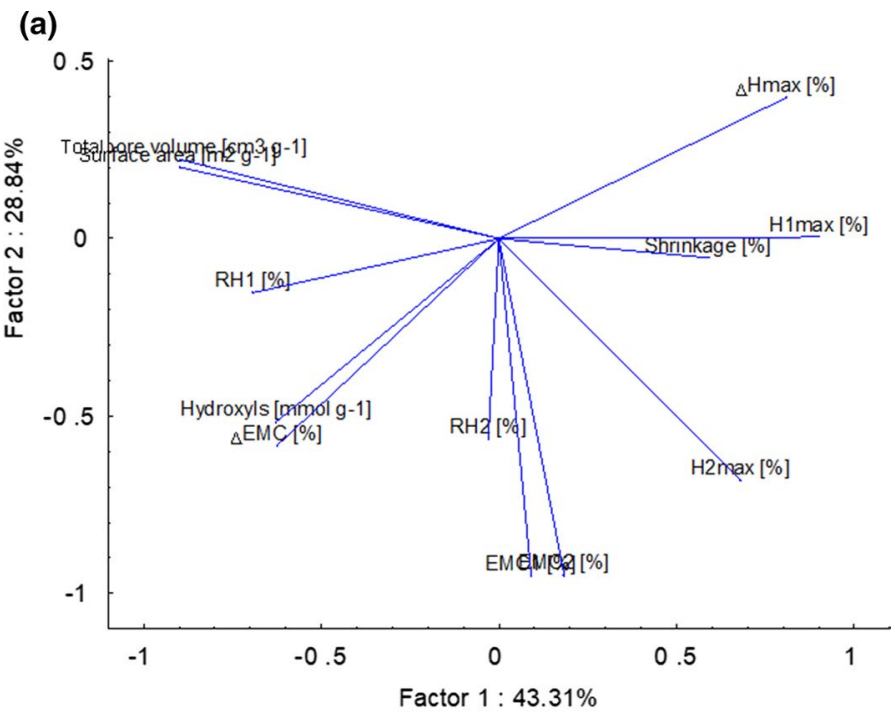

(b)

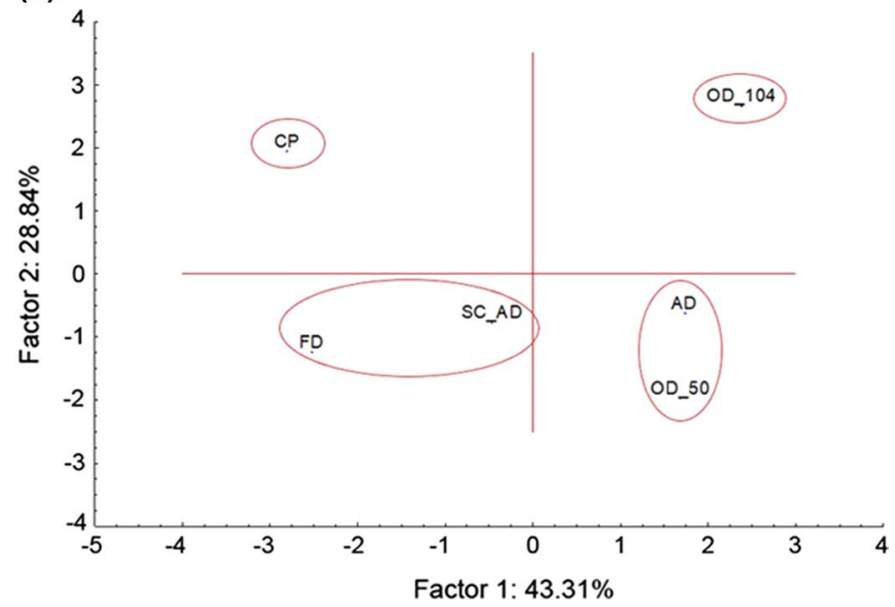

Fig. 7 Principal component analysis regarding all the structure- and moisture-relating data obtained for the cell wall of the studied waterlogged elm samples dried with different methods: a Representation of variables in the space of the first two principal components; b PC1 versus PC2 score plots

upon drying. However, the high levels of hysteresis for these samples compared to solvent-exchanged, freeze- and supercritical-dried ones indicate that the structure can "reopen" upon moisture absorption. No correlations were found between wood structure and EMC or the number of hydroxyls, which indicates that the interactions between wood sorption properties and microstructure in respect of the applied drying methods are more complex.

From a conservators' perspective, it is clear that application of particular drying methods to degraded waterlogged wood not only affects its aesthetic value, but also 
has implications on properties important for both storage and further conservation/ reconservation, for example differences in wood porosity, despite the same degree of wood degradation, will affect permeability to chemicals used for wood conservation thus influence the effectiveness of the treatment, whilst moisture properties will affect further dimensional changes of wood and should be taken into consideration whilst setting up storage/exposition conditions for wooden artefacts.

Funding The research was supported by the STSM Grant (Grant holder Magdalena Broda) from COST Action FP1407 [COST STSM Reference Number: COST-STSM-FP1407-39990].

\section{Declarations}

Conflicts of interest On behalf of all authors, the corresponding author states that there is no conflict of interest.

Open Access This article is licensed under a Creative Commons Attribution 4.0 International License, which permits use, sharing, adaptation, distribution and reproduction in any medium or format, as long as you give appropriate credit to the original author(s) and the source, provide a link to the Creative Commons licence, and indicate if changes were made. The images or other third party material in this article are included in the article's Creative Commons licence, unless indicated otherwise in a credit line to the material. If material is not included in the article's Creative Commons licence and your intended use is not permitted by statutory regulation or exceeds the permitted use, you will need to obtain permission directly from the copyright holder. To view a copy of this licence, visit http://creativecommons.org/licen ses/by/4.0/.

\section{References}

Ambrose WR (1989) Application of freeze-drying to archaeological wood. In: Archaeological wood. American Chemical Society, pp 235-261

Ambrose WR (1990) Application of freeze-drying to archaeological wood. ACS Publications

Barrett EP, Joyner LG, Halenda PP (1951) The determination of pore volume and area distributions in porous substances. I. Computations from nitrogen isotherms. J Am Chem Soc 73:373-380. https:// doi.org/10.1021/ja01145a126

Björdal CG (2012) Microbial degradation of waterlogged archaeological wood. J Cult Herit 13:S118S122. https://doi.org/10.1016/j.culher.2012.02.003

Broda M, Curling SF, Spear MJ, Hill CA (2019) Effect of methyltrimethoxysilane impregnation on the cell wall porosity and water vapour sorption of archaeological waterlogged oak. Wood Sci Technol 53:703-726. https://doi.org/10.1007/s00226-019-01095-y

Broda M, Dąbek I, Dutkiewicz A et al (2020) Organosilicons of different molecular size and chemical structure as consolidants for waterlogged archaeological wood-a new reversible and retreatable method. Sci Rep 10:1-13. https://doi.org/10.1038/s41598-020-59240-8

Brunauer S, Emmett PH, Teller E (1938) Adsorption of gases in multimolecular layers. J Am Chem Soc 60:309-319. https://doi.org/10.1021/ja01269a023

Cave ID (1978) Modelling moisture-related mechanical properties of wood Part I: properties of the wood constituents. Wood Sci Technol 12:75-86. https://doi.org/10.1007/BF00390012

Christensen M, Frosch M, Jensen P et al (2006) Waterlogged archaeological wood-chemical changes by conservation and degradation. J Raman Spectrosc 37:1171-1178. https://doi.org/10.1002/jrs.1589

Dawson BS, Pearson $\mathrm{H}$ (2017) Effect of supercritical $\mathrm{CO}_{2}$ dewatering followed by oven-drying of softwood and hardwood timbers. Wood Sci Technol 51:771-784. https://doi.org/10.1007/ s00226-017-0895-8 
Dawson BS, Pearson H, Kimberley MO et al (2020) Effect of supercritical $\mathrm{CO}_{2}$ treatment and kiln drying on collapse in Eucalyptus nitens wood. Eur J Wood Prod 78:209-217. https://doi.org/10.1007/ s00107-020-01500-5

Diniz JF, Gil MH, Castro J (2004) Hornification-its origin and interpretation in wood pulps. Wood Sci Technol 37:489-494. https://doi.org/10.1007/s00226-003-0216-2

Engelund ET, Thygesen LG, Svensson S, Hill CA (2013) A critical discussion of the physics of woodwater interactions. Wood Sci Technol 47:141-161. https://doi.org/10.1007/s00226-012-0514-7

Esteban LG, De Palacios P, Fernández FG, García-Amorena I (2010) Effects of burial of Quercus spp. wood aged 5910 $\pm 250 \mathrm{BP}$ on sorption and thermodynamic properties. Int Biodeter Biodegr 64:371377. https://doi.org/10.1016/j.ibiod.2010.01.010

Fredriksson M, Thybring EE (2019) On sorption hysteresis in wood: separating hysteresis in cell wall water and capillary water in the full moisture range. PLoS ONE. https://doi.org/10.1371/journal. pone.0225111

Glass SV, Boardman CR, Thybring EE, Zelinka SL (2018) Quantifying and reducing errors in equilibrium moisture content measurements with dynamic vapor sorption (DVS) experiments. Wood Sci Technol 52:909-927. https://doi.org/10.1007/s00226-018-1007-0

Grattan DW (1987) Waterlogged wood. In: Conservation of marine archaeological objects. Elsevier, pp $55-67$

Grattan DW, McCawley JC (1978) The potential of the Canadian winter climate for the freeze-drying of degraded waterlogged wood. Stud Conserv 23:157-167. https://doi.org/10.1179/sic.1978.021

Guo J, Zhou H, Stevanic JS et al (2018) Effects of ageing on the cell wall and its hygroscopicity of wood in ancient timber construction. Wood Sci Technol 52:131-147. https://doi.org/10.1007/ s00226-017-0956-Z

Jackson JE (2005) A user's guide to principal components. Wiley, Hoboken

Jiachang C, Donglang C, Jingen Z et al (2009) Shape recovery of collapsed archaeological wood ware with active alkali-urea treatment. J Archaeol Sci 36:434-440. https://doi.org/10.1016/j.jas.2008.09. 027

Jian-xiong L, Zhi-yuan L, Jia-li J, Jing-hui J (2005) Liquid penetration of freeze-drying and air-drying wood of plantation Chinese fir. J for Res 16:293-295. https://doi.org/10.1007/BF02858192

Kaye B, Cole-Hamilton DJ, Morphet K (2000) Super critical drying: a new method for conserving waterlogged archaeological materials. Stud Conserv 45:233-252.

Kimura M, Qi Z-D, Isogai A (2016) Analysis of mesopore structures in wood cell walls and pulp fibers by nitrogen adsorption method. Nord Pulp Paper Res J 31:198-204. https://doi.org/10.3183/ npprj-2016-31-02-p198-204

Kojiro K, Miki T, Sugimoto H et al (2010) Micropores and mesopores in the cell wall of dry wood. J Wood Sci 56:107-111. https://doi.org/0.1007/s10086-009-1063-Z

Lee K-Y, Quero F, Blaker JJ et al (2011) Surface only modification of bacterial cellulose nanofibres with organic acids. Cellulose 18:595-605. https://doi.org/10.1007/s10570-011-9525-Z

McKerrell H, Roger E, Varsanyi A (1972) The acetone/rosin method for conservation of waterlogged wood. Stud Conserv 17:111-125. https://doi.org/10.1179/sic.1972.011

Nguyen TD, Sakakibara K, Imai T et al (2018) Shrinkage and swelling behavior of archaeological waterlogged wood preserved with slightly crosslinked sodium polyacrylate. J Wood Sci 64:294-300. https://doi.org/10.1007/s10086-018-1696-x

Ormondroyd GA, Källbom SK, Curling SF et al (2017) Water sorption, surface structure and surface energy characteristics of wood composite fibres refined at different pressures. Wood Mat Sci Eng 12:203-210. https://doi.org/10.1080/17480272.2016.1150343

Perre P, Keey RB (2006) Drying of wood: principles and practices. In: Handbook of industrial drying. CRC Press, pp 846-903

Rautkari L, Hill CA, Curling S et al (2013) What is the role of the accessibility of wood hydroxyl groups in controlling moisture content? J Mater Sci 48:6352-6356. https://doi.org/10.1007/ s10853-013-7434-2

Redman AL, Bailleres H, Perré P et al (2017) A relevant and robust vacuum-drying model applied to hardwoods. Wood Sci Technol 51:701-719. https://doi.org/10.1007/s00226-017-0908-7

Redman AL, Bailleres H, Turner I, Perré P (2016) Characterisation of wood-water relationships and transverse anatomy and their relationship to drying degrade. Wood Sci Technol 50:739-757. https:// doi.org/10.1007/s00226-016-0818-0

Salmén L (2015) Wood morphology and properties from molecular perspectives. Ann for Sci 72:679_ 684. https://doi.org/10.1007/s13595-014-0403-3 
Salmén L, Stevanic JS (2018) Effect of drying conditions on cellulose microfibril aggregation and "hornification.” Cellulose 25:6333-6344. https://doi.org/10.1007/s10570-018-2039-1

Spear MJ, Broda M (2020) Comparison of contemporary elm (Ulmus spp.) and degraded archaeological elm: the use of dynamic mechanical analysis under ambient moisture conditions. Materials 13:5026. doi:https://doi.org/10.3390/ma13215026

Thybring EE, Thygesen LG, Burgert I (2017) Hydroxyl accessibility in wood cell walls as affected by drying and re-wetting procedures. Cellulose 24:2375-2384. https://doi.org/10.1007/s10570-017-1278-X

Welling J, Schwarz T, Bauch J (2018) Biological, chemical and technological characteristics of waterlogged archaeological piles (Quercus petraea (Matt.) Liebl.) of a medieval bridge foundation in Bavaria. Eur J Wood Prod 76:1173-1186. https://doi.org/10.1007/s00107-018-1299-7

Yin J, Song K, Lu Y et al (2015) Comparison of changes in micropores and mesopores in the wood cell walls of sapwood and heartwood. Wood Sci Technol 49:987-1001. https://doi.org/10.1007/ s00226-015-0741-9

Publisher's Note Springer Nature remains neutral with regard to jurisdictional claims in published maps and institutional affiliations. 